Open Access

\title{
Americanization in Lithuania as a driving force for globalization
}

\author{
Agnè Šimelytè ${ }^{1 *} \mathbb{D}$, Renata Korsakienè ${ }^{1}$ and Deniss Ščeulovs ${ }^{2}$
}

\author{
* Correspondence: \\ agne.Simelyte@Vgtu.Lt \\ ${ }^{1}$ Faculty of Business Management, \\ Vilnius Gediminas Technical \\ University, Sauletekio av. 11, \\ LT-10223 Vilnius, Lithuania \\ Full list of author information is \\ available at the end of the article
}

\begin{abstract}
Purpose: The purpose of the article is to analyze Americanization patterns in Lithuania by exploring socio-economic and cultural factors and to determine the impact of Americanization on the level of globalization of the country and its economy.

Design/ methodology: The research employs both qualitative and quantitative methods by using primary and secondary data. Further descriptive statistics, correlation regression, and factor analysis is applied. Carrying out the survey has collected primary data. Secondary data was drawn from the Statistics Lithuania, Premiercapital, and Swiss Federal Institute of Technology Zurich.
\end{abstract}

Findings/ outcomes: The obtained and analyzed information on the spread of foreign capital, culture and their impact on social and cultural life in the host country which results in emigration and brain drain problems. On the other hand, the research allows us to examining the behavior of Lithuanians and their abilities to accept new culture and social life on the basis of own wealth. The results show that Americanization has much significant impact on economic growth rather than on globalization in Lithuania.

Originality/ value: It is an interdisciplinary research, which covers three scientific areas: sociology, economics and mathematics. It is unique as it extends to the theory of globalization and synthesizes both understandings of Americanization: cultural assimilation and Americanization as the form of internationalization.

Keywords: Globalization, Americanization, McDonaldization, Lithuania Jel: F6

\section{Introduction}

The movement of capital, people and goods naturally transfers some information, habits, and culture. Even more, the expansion of the companies into international area causes the transfer of knowledge and technologies to host country. Thus, processes or products created for one market are adapted to another one. In this way, processes are unstoppable and identity, habits, and way of life are shifted to another location. However, not all countries manage to expand their culture and values or even invade other cultures. Meanwhile, the U.S. since at least the end of the nineteenth century has exported certain products, techniques, fashions, investment, and art, as well as people (Burke, 2014; Yun, et al., 2016; Albaugh, 2017). Thus, by the end of twentieth century and beginning of the twenty-first century, American culture has expanded to largest part of the world. For that reason, some scientists nearly equally define Americanization and globalization. They 
emphasize that Americanization process does not involve only goods, services, entertainment, communication, business and technologies but it is more referred to assimilation and invasion of cultures, as primary definition of Americanization process was policy on assimilating immigrants (Lauret, 2013). Assimilation usually has negative meaning. However, assimilation might be also referred as how faster to integrate immigrants into society. Fast expansion of American production, technologies, fashion and entertainments has created the culture of consumption that results increase in consuming and supposed to boost local economy.

Thus, the purpose of the article is to analyze Americanization patterns in Lithuania by exploring socio-economic and cultural factors and to determine the impact of Americanization on the level of globalization of the country and its economy.

For methodological purposes the article is divided into three parts. First parts analyses concepts of globalization, Americanization, and McDonaldization. The second part describes methodology and data of the research. The last part analyses Americanization patterns in Lithuania and interprets results of the empirical research.

\section{The concept of globalization, Americanization, and Mcdonaldization}

Scientific literature provides various definitions, forms of globalization, and factors determining globalization. It even might be stated that globalization is the multidimensional process with the hundreds of varying definitions. Although Tomja (2013) claims that globalization, as a term has not been known until 25 years ago, however Jiafeng (2009) maintains that the theory of globalization gradually took over the theory of modernization. Khaniha and Fard (2009) divide globalization into three different historical processes: expansion of information technology, renewal of capitalism structure and collapse of bipolar system. Radu (2009) and Craig et al. (2008) state that globalization process is the economic phenomenon.

Bond and O'Bryne (2014) describe eight models of global change depending on different levels of socio-economic, political, cultural and other processes (Table 1): globalization, liberalization, polarization, Americanization, McDonaldization, creolization, transnationalization and balkanization. In addition, scientific literature provides Europeanization,

Table 1 Models of Global Change (Source: based on Bond and O'Byrne, 2014; Graziano \& Vink, 2013; Craig et al., 2008; Khondker, 2004; Ritzer, 1983)

\begin{tabular}{ll}
\hline Model & Image of World Society \\
\hline Globalization & Orientation to "one world" \\
Piberalization & Erosion of barriers between nation-states \\
Americanization & World divided into rich and poor \\
McDonaldization & American empire sustained through hard and soft power \\
Creolization & Standardization of practices across the world \\
Europeanization & Ongoing local transformation through regional flows \\
Transnationalization & Process of domestic adaptation to European regional integration. \\
Internationalization & Emerge of level of governance above the nation state. \\
Glocalization & Expansion of a company beyond the home market to other countries. \\
Balkanization & Creation of products or services intend for global market but \\
\end{tabular}


Westernization, glocalization and internationalization models (Alcadipani \& Caldas, 2012; Martens et al., 2015).

Moreover Adams (2007) claims that in addition to economic and technological changes, globalization increases reflexivity. Even more, it changes quantitative social processes which are not necessary new themselves but new to different geographical areas. The expansion of companies internationally has increased consumption of products, which are created for global market even such as entertainment products (movies and music). Meanwhile, the most popular music genders such as rock, rap and hip-hop have American roots. The most popular movies and TV series such as "Sex and the City", "Friends", "Big Bang Theory", "Simpsons" or "American Dad" are created in Hollywood, which again represent American culture and values. Most of these TV shows are based on daily Americans' habits, routine, way of communication with each other, understanding of the world and even diet.

However, the scientific literature provides two different approaches towards Americanization. Huebner (1906) and Butler (1920) describe Americanization as the process of immigrants' integration into the society, assimilation and transformation into Americans. Maes and Buyst (2005) have found some signs of Americanization in interwar Belgium and associated it with migration to the U.S. in the 1920s. Due to the expansion of American corporations to Europe at that time, some of the European researchers have seen Americanization as a threat to their customs and cultural values (Bonin \& de Goery, 2009; von Mahs, 2011). Americanization refers to cultural transfer (Kuisel, 2001). Belgian economists Maes and Buyst (2005) claim that Americanization, as internalization, is neither entirely satisfactory nor entirely avoidable. Later, Americanization has been defined as the form of modernization (Tipps, 1973) and a specific type of globalization (Craig et al., 2008). However, there are some differences between modernization and globalization or Americanization. Both globalization and Americanization theory stress the interrelationship among countries and process, in which these countries become "one" in globalization case or adopt American culture in Americanization case. While the modernization theory emphasizes the progress and development of a country or region (Jiafeng, 2009), Dahrir (2013) claims that Americanization and cultural globalization are the synonyms. However, differently than Americanization, cultural globalization is seen as competition and negotiation process as countries attempt to preserve their position and culture in global area (Adams, 2007). Meantime, Americanization might be described as an invasion of American culture, customs, and values.

Xifra (2011) analyses the phenomena of Americanization of politics in Spain, particular Catalonia. It has been found that candidates adopt strategies of American campaigns, which are more built around the personality rather than the party. For example, even logotypes have been created with candidates' name and communication is based on his or her figure. Xifra (2011) also observes some similarities of American campaign in "video battles". Nielsen (2013) agrees with Xifra (2011) and states that Americanization has invaded media. Moreover, Scheindlin (2017) claims that marketing has been highly affected by Americanization. Tomja (2013) notices that products and American way of lifestyle and values expand much more quickly than culture and habits of other countries.

To explain cultural globalization and sociological phenomenon, Ritzer (1983) introduces McDonaldization definition. Later, First and Avraham (2007) portray McDonaldization as "cultural imperialism" which is the consequence of cultural homogenization 
that leads to Americanization of culture. Originally, McDonaldization is characterized as "the process by which the principles of the fast-food restaurant are coming to dominate more and more sectors of American society as well as of the rest of the world" (Ritzer \& Chen, 2015). According to McDonaldization concept, standardization, regulation and homogenization are the features of successful and effective business (Bond \& O'Byrne, 2014). McDonaldization as a process of rationalization supposed to be based on four dimensions: efficiency, calculability, predictability, and control (Ritzer, 1983). In this case, efficiency refers to rational and the most optimum model of production where individualism is not allowed. Calculability is seen as an assessment of output process, which is based on quantity rather than quality. Predictability describes production process, which is organized to assure uniformity of product and standardized outcomes. Control is associated with substitution of human labor force through automation.

Chun (2012) equally understands both McDonaldization and Americanization since the last definition refers to standardizing lifestyle and mindset of society. Thus, globalization has invaded economy, culture, media, politics and etc. (Tomja, 2013).

To conclude it might be stated that both McDonaldization and Americanization represent political, cultural, technological uniformity and homogeneity, which have influence on economic, cultural, political and technological changes and economic growth.

\section{Methods}

Scientific literature provides plenty of studies on Americanization (Ritzer, 1983; First \& Avraham, 2007; Craig et al., 2008; Xifra, 2011; Lleras-Muney \& Shertzer, 2015; Ritzer \& Chen, 2015; Oxelheima \& Randoya, 2013), globalization (Jiafeng, 2009; Khaniha \& Fard, 2009; Zinkina et al., 2013; Chun, 2012; Yun, 2015; Yun et al., 2016), and internationalization (Šimelytė et al. 2014; Albaugh, 2017). However, majority of researchers have (Radu, 2009; Xifra, 2011; Tomja, 2013) analyzed cases and provided examples of Americanization patterns and just few have employed quantitative methods (Table 2).

First and Avraham (2007) have studied Americanization in Israel by applying qualitative analysis based on semiotic interpretation of texts. The sample included 489 fullpage advertisements. For example, Craig et al. (2008) divide their methodology into two stages: preliminary analysis and regression analysis. In order to examine interrelationship and to identify possible sources of inter-correlation as well as to reduce the number of independent factors, Craig et al. (2008) have conducted explanatory factor analysis on ten variables representing Appadurai's five cultural flows. Lleras-Muney \& Shertzer (2015) analyze Americanization as process of assimilating immigrants by using three cross-sections from 1910 to 1920, 1930, and developed the probit model. The research of Lleras-Muney \& Shertzer (2015) disclose that Americanization as policy to assimilate immigrants has failed.

Thus, concluding it might be stated that many scholars understand Americanization as a form of globalization; usually studies of Americanization are based on case analysis or other qualitative methods rather than quantitative approach, while the level of globalization mostly is expressed in indices.

Such indices include economic, political, social, and other process. The well known are the following indices (Pekarskiene \& Susniene, 2011; Zinkina et al., 2013; Martens et al., 2015): 
Table 2 Summary of studies on Americanization and globalization (Source: compiled by the authors)

\begin{tabular}{|c|c|c|}
\hline Authors and year & Object of research & Methods used \\
\hline Kuisel (2001) & Americanization & Case analysis / semiotics \\
\hline Adams (2007) & $\begin{array}{l}\text { Globalization / } \\
\text { Americanization }\end{array}$ & Case analysis / semiotics \\
\hline $\begin{array}{l}\text { First \& Avraham } \\
\text { (2007) }\end{array}$ & Americanization & Qualitative analysis of advertising in Israel (semiotics) \\
\hline Craig et al. (2008) & Americanization & Factor analysis, correlation- regression analysis \\
\hline $\begin{array}{l}\text { Pekarskiene \& } \\
\text { Susniene } 2011\end{array}$ & Globalization & Indices, correlation-regression \\
\hline Von Mahs (2011) & Americanization & Literature review, description of the case \\
\hline Xifra (2011) & Americanization & Qualitative analysis/ semiotics \\
\hline $\begin{array}{l}\text { Alcadipani \& Caldas } \\
\text { (2012) }\end{array}$ & Americanization & Theoretical concepts, case analysis \\
\hline $\begin{array}{l}\text { Lleras-Muney \& } \\
\text { Shertzer (2015) }\end{array}$ & Americanization & $\begin{array}{l}\text { Three cross-sections from } 1910 \text { to 1920, 1930, and developed } \\
\text { the probit model }\end{array}$ \\
\hline Albaugh (2017) & Americanization & Collection of primary data, descriptive statistics \\
\hline Scheindlin (2017) & Americanization & $\begin{array}{l}\text { Qualitative analysis of Americanization patterns in mass media, } \\
\text { marketing culture and politics. }\end{array}$ \\
\hline
\end{tabular}

- Maastricht globalization Index;

- KOF globalization index measures three main dimensions: economic, social, and political. The methodology of calculating overall globalization index and sub-indices refers to actual economic flows, economic restrictions, data on information flows, and data on personal contact and cultural proximity.

- T. Kerney foreign policy magazine index;

- Globalization index by the Centre for the study of Globalization and Regionalization at Warwick University;

- Ernst \& Young annual globalization index which is based on openness to trade, capital flows, exchange to technology and ideas, labor movements and cultural integration;

- Global index by TransEurope Research Network is an aggregated index, which includes four main dimensions: economic, socio-technical, cultural, and political.

The main weakness of the most popular globalization indices (KOF globalization Index and Kerney foreign policy magazine index) is that cultural factors are included in socio-economic factors.

The analysis of scientific literature suggests that Americanization is one of the forms of globalization. Thus, it might be assumed that the factors of Americanization supposed to be similar to the factors of globalization. For that reason, we divide the factors of Americanization into three groups: economic, social, and cultural. Economic factors involve: import from the U.S. (thousands of euros), FDI from the U.S. (thousands of euros). Social factors are divided into two groups: personal contacts and information flow. Personal contacts are expressed as arrivals of tourists from the U.S. (number of nights per person), number of Americans living in Lithuania (number of people), emigrants into the U.S. (number of people). Information flow covers: access to the Internet (number of users) and television (number of television subscribers). Cultural factors involve cinema (number of visitors in thousands) and McDonald restaurants (revenue per capita). 
Thus, for evaluating the relationship between Americanization and globalization in Lithuania, as one of independent variables KOF globalization index is used. To measure the impact of Americanization factors on the economy of Lithuania, real GDP per capita is used.

The data of this research has been drawn from Statistics Lithuania, Premiercapital, and Swiss Federal Institute of Technology Zurich.

The Methodology of the research is divided into three stages.

The purpose of the first stage is to reduce the number of Americanization factors influencing globalization in Lithuania. For that reason, factor analysis has been employed. This unique technique summarizes the information from a set of variables into a smaller set of factors. Each factor is composed of variables that correlate highly with each other and interact weakly with the variables present in other factors (Perobelli \& De Oliveira, 2013). The factor is associated with variables, if absolute values of are equal or higher than 0.4. The common factor's score is generated according to the formula:

$$
\widehat{F}_{j}=\sum_{i=1}^{k} b_{i j} z_{i}
$$

where $\hat{F}_{j}$ - score of factor; $b_{i j}$ - value of correlation coefficient; $z_{i}$ - standardized value of $i^{\text {th }}$ variable.

The second stage of the research estimates the relationship among the most significant Americanization factors, KOF globalization index and the growth of Lithuanian economy. For this purpose, correlation-regression analysis is applied.

The purpose of the third stage is to find out how young people imagine life quality, wealth, culture and democracy in the United States and Europe. According to Statistics Lithuania, in 2016, 50,333 people have emigrated from Lithuania, more than $12 \%$ of them are at age of 18 to 22. It is expected that this part of research would reveal main reasons determining the migration of young people from Lithuania to the U.S. or other European countries. Thus, the questionnaire is based on main stereotypes and myth or images of the U.S. and Europe that mass media creates. The questionnaire covers both qualitative and quantitative questions. The first part covers four open questions, which are dedicated to find out how young people understand globalization in general, how they understand Americanization, its negative and positive impacts on Lithuanian culture and economy. They were also asked "what does it mean to be European". The fifth question asked to associate 19 given stereotypes either with the United States or Europe. For data processing of this question, descriptive statistics has been used. Answers are given into two-point scale: 1 as numerical value is assigned to the U.S. and 2 is assigned to Europe.

The survey of young people between the ages of 18-21 has been carried out.

\section{Americanization patterns in Lithuania and the Discusion of the results}

The evidence of Americanization can be found even in interwar Lithuania as worldwide acknowledged brands, such as Ford Motors, Wrigley, Chevrolet, Chrysler, Gillette and others, were well known at that time (Minkevičius, 2015). WWII and the Soviet annexation suspended the process of Americanization as internationalization for fifty years. 
After the collapse of the Soviet Union, Lithuania joined the free market system, started privatization process, and reestablished a business relationship with American corporations, which dominated during the interwar period. From the 1990s the expansion and penetration of American corporations into the Lithuanian market, in the forms of foreign direct investment (FDI) and international trade, made a remarkable impact on the economic growth. Even more, these significant changes went beyond the economic impacts. The movement of goods, capital, information and labor across the borders has transformed social and cultural habits.

At this moment, the American capital companies employ 11,548 people in Lithuania. Most of the companies are located in Vilnius and Kaunas. The peak of American capital companies has been reached in 2004 (Fig. 1.). Later the number of companies decreased. It might be explained by the fact that American capital companies have found more favorable business environment than in Lithuania.

However, some companies, for example AIG American Multinational Corporation for the first time invested in Lithuania in 2002-2004. Due to the financial crisis, parenting company suffered loss, thus, it has been forced to close some affiliates over the world. In 2014 American International Group reinvested in Lithuania and currently employs more than 100 people. A number of branches of large global corporations operate in Lithuania such as Cisco, IBM, Microsoft, Best Western, Western Union, CocaCola HBC Lithuania, Google Lithuania, Delloite, McDonalds and others. The expansion of well-known American companies in Lithuania did not stop emigration.

The highest number of emigrants into the U.S. has been reached in 2004 (Fig. 2). Meanwhile in 2014 the migration into the U.S. has decreased eight times. However, statistical data reveal significant high emigration rate, which means that people choose different countries such as United Kingdom, Ireland, Norway, and Germany. In the meantime, Lithuania faces with emigration and brain drain problems. The level of emigration has been increasing since the 1990s. Thus, it might be assumed that emigration and brain drain are the consequences of globalization.

Data set of variables determining Americanization has been checked for adequacy and reliability by calculating Cronbach's Alpha, KMO and Bartlett's Test of Sphericity. The obtained results has indicated that data is suitable for further investigation, since the numbers are equal to 0.740 and 0.639 respectively, and the result of Bartlett's test is below 0.05. Total explanation variance and component matrix reveal that there are

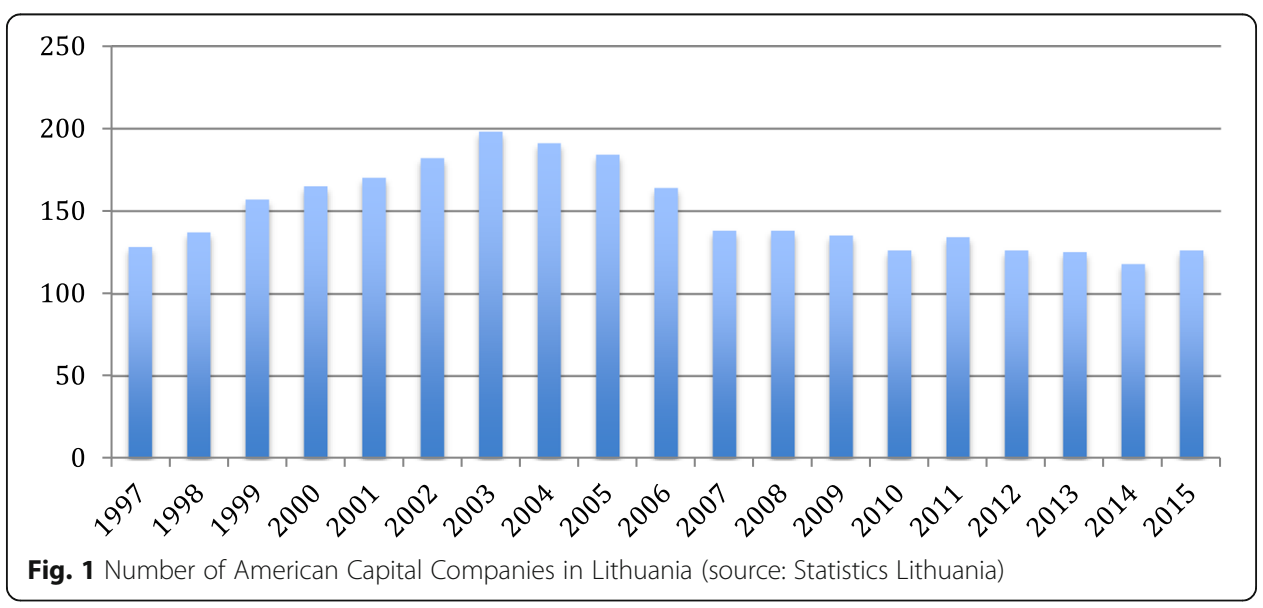




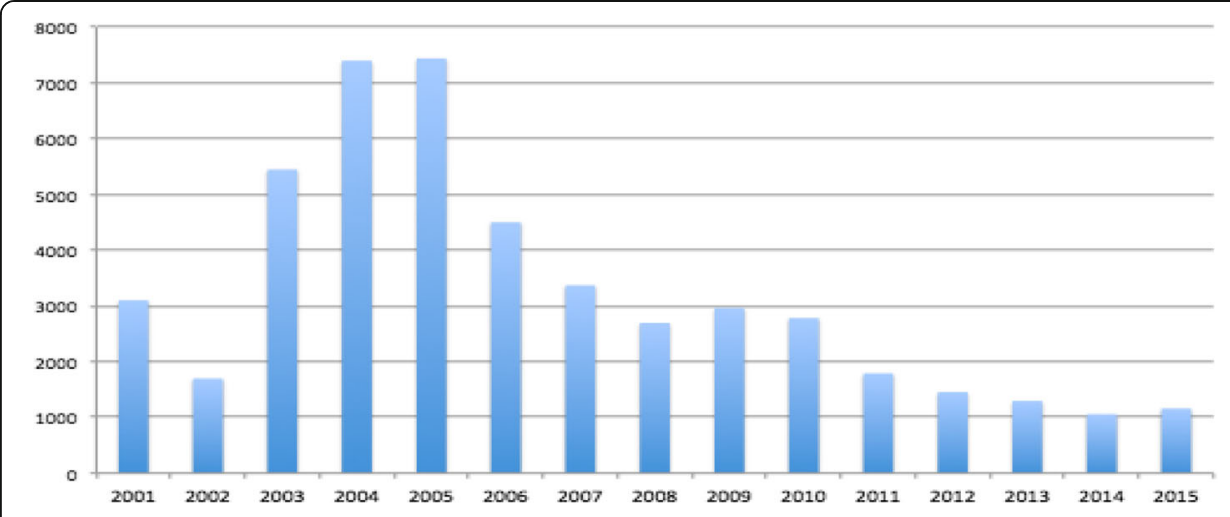

Fig. 2 Migration to the U.S. (source: Statistics Lithuania)

seven factors that interpret selected variables (Table 3); however, the factors which eigenvalues are higher than one have been taken for further research. Thus, first factor explains $74 \%$ of total variance and the second one $-15 \%$ of total variance. Both eigenvalues are higher than one. The variables with the highest loadings on the first factor are television, emigration into the U.S., and import form the U.S. with loadings 0.938 , -0.939 and 0.917 respectively. This suggests that commercials have impact on acquiring products from the United States. Even more, this suggests that people have access to various American TV shows, TV series, or movies. Meanwhile, cinema has lower loading which indicates that people observe and adopt American culture and lifestyle while watching TV, internet has even lower loading but still significant. The variables with highest loadings on the second factor are number of Americans, Internet and McDonalds with loadings $0.905,0.721$, and 0.694 respectively.

Although, the study of Pekarskiene and Susniene (2011) shows that all Baltic States have reached a high globalization level, the results of regression analysis (Table 4) disclose that factors of Americanization are insignificant on globalization in Lithuania. First regression has been run between KOF globalization index as dependent variable and independent variables Factor 1 and Factor 2. Hence, $R$ and $R^{2}$, t-statistics and Fisher's statistics show that first model is not significant. Meantime, the modeling of

Table 3 Rotated Component Matrix

\begin{tabular}{lll}
\hline & Component & \\
\cline { 2 - 3 } & 1 & 0.355 \\
\hline Import from the U.S. & 0.917 & 0.149 \\
FDI from the U.S. & -0.881 & 0.606 \\
Tourists from the U.S. & 0.641 & -0.270 \\
Emigration into the U.S. & -0.949 & 0.905 \\
Number of Americans & -0.116 & 0.721 \\
Internet & 0.614 & 0.245 \\
Television & 0.938 & 0.576 \\
Cinema & 0.795 & 0.694 \\
McDonalds & 0.668 & 1.402 \\
Eigenvalue & 6.676 & 15.58 \\
Percent explained variance & 74.17 & \\
\hline
\end{tabular}


Table 4 Results of regression analysis

\begin{tabular}{lllllll}
\hline Dependent variable & Factor 1 & Factor 2 & $\mathrm{R}$ & $\mathrm{R}^{2}$ & F-statistics & Significance \\
\hline KOF globalization index & $-0.163^{\mathrm{a}}$ & 0.459 & 0.487 & 0.237 & 0.777 & Insignificant \\
& $(-0.417)^{\mathrm{b}}$ & $(1.175)$ & & & & \\
Real GDP per capita & 0.836 & 0.516 & 0.982 & 0.965 & 69.443 & Significant \\
& $(10.032)$ & $(6.184)$ & & & & \\
\hline
\end{tabular}

${ }^{\mathrm{a}} \beta$ - standardized coefficients; ${ }^{\mathrm{b}}$ - t statistics

second equation proves its significance. Thus, Americanization has impact on economy growth. There is a strong relationship between Factor 1 and economic growth. The increase of Factor 1 by $1 \%$ would cause the growth of economy by $0.836 \%$. The increase of Factor 2 by $1 \%$ would boost real GDP per capita by $0.516 \%$.

Results of bivariate correlation display that real GDP per capita has strong relationships among almost all determinants of Americanization in Lithuania. The highest ratios are between real GDP per capita and revenue of McDonald restaurants, import from the U.S. and number of cinema visitors (Table 5). Meanwhile, negative medium significant value is observed between economic growth and inward FDI from the U.S. In recent years, the number of American capital companies has been decreasing as well as inward FDI from the U.S has shrunk 45\% from 2009 to 2012. For the last four years American FDI has been slightly growing up every year, however it still has not reached the same level as in 2009. Bivariate correlation shows that FDI from the U.S. has negative values almost in all cases, except number of Americans and emigration into the U.S. Thus, these fluctuations might have caused such negative results. Strong negative impact has been noticed between economic growth and emigration into the U.S. Compared with other factors, the number of Americans living in Lithuania has the least impact on economic growth. There are strong interlinks among McDonalds, cinema, import from the U.S. and the Internet which allows to make a conclusion that main determinants of Americanization and their variables are significant in Lithuania and have impact on economic growth.

The survey has been conducted in early 2016. 189 young people from age of 18 to 21 answered the questions. $46 \%$ of respondents are female, the others $54 \%$ males. All respondents are students. The answers of how they understand or define globalization are similar as provide scientific literature. Most of answers refer that globalization covers all aspects of life, all processes in society, free movement of goods and people, migration, cultural assimilation, other social factors. One of them even associates globalization with the sales and popularity of iPhones. Another respondent states: "globalization is emerge of the world". The other defines similar as Bond and O'Byrne (2014). Globalization is "the process to become one world".

Respondents associate Americanization with restaurants such as McDonald and Hesburger, computer games, movies, and Halloween. Most of the female respondents mention McDonald as negative factor influencing life. As negative aspects young people see too quickly adopting new cultural habits from the U.S. One of the respondents specifies that young people very often use American slangs and words in their speech while speaking Lithuanian. However, most of respondents maintain that the U.S. has positive impact on Lithuanian economy and business. Even more, young people believe that transfer of American corporate culture would bring more success to Lithuanian business companies. 


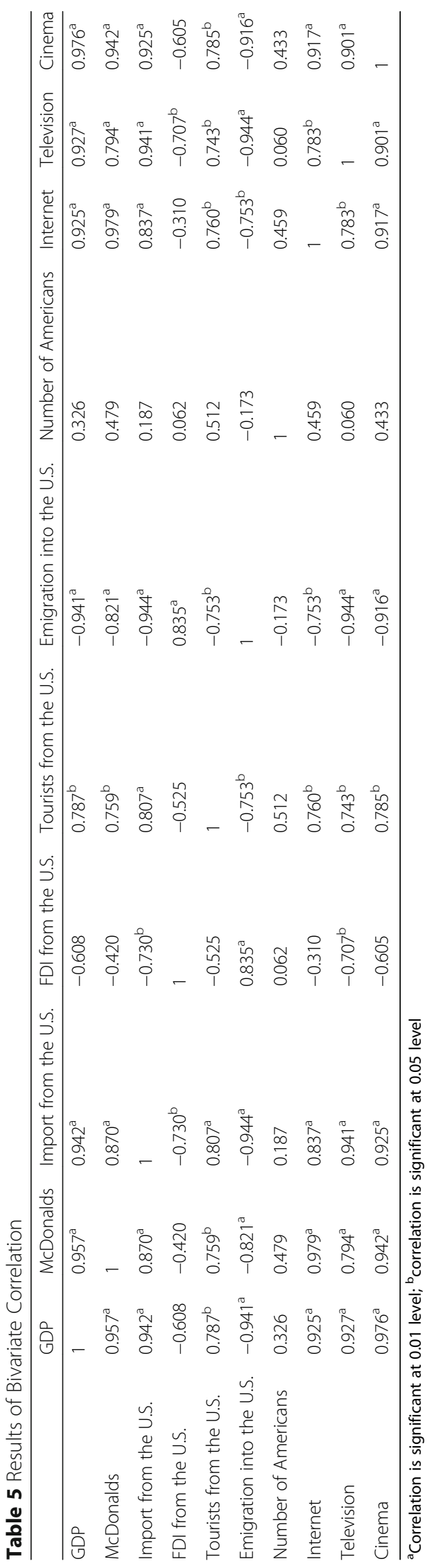


Young people have provided various answers of what means to be European. But most answers describe that being European is to part of European society, part of European culture. Some respondents have associated being European with a membership in the European Union, while the others state that membership in the EU does not make European. Few of respondents claim that European is the person who lives in Europe.

Results of survey clarify some stereotypes young people have of United States and Europe and how they affect people's life (Table 6). For example, almost $100 \%$ of whole respondents think that people wealthier live in the U.S. rather than in Europe, even more better opportunities and success are more associated with the USA. Democracy and personal independence are nearly equally associated with both the U.S. and Europe. Young people believe that security of the country, education, health security are greater in Europe. Meanwhile, supply of products for daily use, entertainment and pleasure are more associated with the U.S. On the other hand, art is linked with Europe.

The United States are more associated with assimilation and abuse of rights, while Europe with integration and respect of cultures and human rights. Respondents assume that they would receive more objective information in Europe in comparison to the U.S. Development, improvement, and innovations are linked with both Europe and the U.S. equally.

To sum up, it might be noticed that there are some evidence that Americanization exists in Lithuania. However, it has greater influence on economic growth and culture rather than on globalization as overall. On the other hand, the main determinants of Americanization such as McDonald restaurants, import from the U.S., which represents availability of products, and services and number of visitors in cinema had strong positive relationships with economic growth.

Table 6 Associations: the U.S. vs EU

\begin{tabular}{|c|c|c|c|c|c|c|}
\hline & \multirow{2}{*}{$\begin{array}{l}\text { Mean } \\
\text { Statistic }\end{array}$} & \multirow{2}{*}{$\begin{array}{l}\text { Std. Deviation } \\
\text { Statistic }\end{array}$} & \multicolumn{2}{|c|}{ Skewness } & \multicolumn{2}{|l|}{ Kurtosis } \\
\hline & & & Statistic & Std. Error & Statistic & Std. Error \\
\hline Democracy & 1.45 & 0.51042 & 0.218 & 0.512 & -2.183 & 0.992 \\
\hline Wealth & 1.00 & 0.00000 & & . & & \\
\hline Security & 1.80 & 0.41039 & -1.624 & 0.512 & 0.699 & 0.992 \\
\hline Supply of Products for Daily Use & 1.35 & 0.48936 & 0.681 & 0.512 & -1.719 & 0.992 \\
\hline Health Security & 1.75 & 0.44426 & -1.251 & 0.512 & -0.497 & 0.992 \\
\hline Education & 1.60 & 0.50262 & -0.442 & 0.512 & -2.018 & 0.992 \\
\hline Art & 1.70 & 0.47016 & -0.945 & 0.512 & -1.242 & 0.992 \\
\hline Entertainment & 1.15 & 0.36635 & 2.123 & 0.512 & 2.776 & 0.992 \\
\hline Pleasure & 1.35 & 0.48936 & 0.681 & 0.512 & -1.719 & 0.992 \\
\hline Personal Independence & 1.45 & 0.51042 & 0.218 & 0.512 & -2.183 & 0.992 \\
\hline Objective Information & 1.75 & 0.44426 & -1.251 & 0.512 & -0.497 & 0.992 \\
\hline Propaganda & 1.25 & 0.44426 & 1.251 & 0.512 & -0.497 & 0.992 \\
\hline Better Opportunities, Success & 1.10 & 0.30779 & 2.888 & 0.512 & 7.037 & 0.992 \\
\hline Development, Improvement, Innovations & 1.50 & 0.51299 & 0.000 & 0.512 & -2.235 & 0.992 \\
\hline Respect for Local Culture & 1.80 & 0.41039 & -1.624 & 0.512 & 0.699 & 0.992 \\
\hline Integration & 1.60 & 0.50262 & -0.442 & 0.512 & -2.018 & 0.992 \\
\hline Assimilation & 1.35 & 0.48936 & 0.681 & 0.512 & -1.719 & 0.992 \\
\hline Respect for Human Rights & 1.55 & 0.51042 & -0.218 & 0.512 & -2.183 & 0.992 \\
\hline Abuse of Rights & 1.40 & 0.50262 & 0.442 & 0.512 & -2.018 & 0.992 \\
\hline
\end{tabular}




\section{Conclusions}

The analysis of scientific literature has revealed that there are two approaches towards Americanization. The first one refers to Americanization as assimilation of immigrants. Or in other words the way or policy how to turn immigrants faster into "Americans". Actually, this approach has been more relevant at the end of nineteenth century or beginning of 20th. Meanwhile the second approach of Americanization is understood as a form of globalization. Although some researchers describe different models of global changes, however there is no single definition neither of globalization nor Americanization. Scholars agree that Americanization more refers to transfer of cultural habits. Thus, in order to define cultural and social globalization, McDonaldization concept has been developed.

Although globalization is evaluated by indices, however most of studies on Americanization employ only qualitative research methods, case analysis or provide some examples. Meanwhile, if Americanization is determined as a form of globalization, this means that it might be evaluated by similar variables as globalization. Thus, in order to reach the purpose of the research, the methodology of three stages has been chosen.

The factor analysis has revealed that Americanization in Lithuania is determined by two factors while are compiled of nine variables with different loadings. Variable with the highest loadings are television, emigration into the U.S., and import from the U.S. The first variable represents transfer of cultural values, lifestyle, and habit through TV shows, commercials, or American New channels. The second variable represents transfer of American values from emigrants. The third variable shows the availability of American products and services in the country. Results of regression analysis provided evidence that Americanization in Lithuania has no significance on globalization (KOF globalization index). However, it does have impact on the growth of economy. The increase of both factors would positively influence real GDP per capita. Bivariate correlation analysis has disclosed that relationship among main indicators describing Americanization and economic growth are strong and positive. The survey shows that young people associate the U.S. with entertainment, pleasure, assimilation and propaganda; while Europe is more associated with security, respect to other cultures, integration and art. At the same time, young people see lot of negative factors of Americanization which influencing life style and habits, or even own language. Open questions reveal that McDonald has become a symbol of negative influence of American culture.

To sum up, there are some Americanization patterns in Lithuania, which have cultural, and economic impact; however it does not have significance on the overall level of globalization.

\section{Acknowledgements}

This paper was received 'best paper award' at SOItmC 2017 conference.

\section{Authors' contribution}

AŠ mainly responsible for executing the study, collecting data, and its analysis. She reviewed previous literature, performed bivariate correlation, factor and regression analysis. Also provided insights on the results. RK prepared the questionnaire and carried out the survey and provided insights on the results of the survey. DŠ collected secondary data from Statistics Lithuania, Premiercapital, and Swiss Federal Institute of Technology Zurich, critically evaluated the paper and provided some insights on conclusions. All authors read final manuscript. 


\section{Publisher's Note}

Springer Nature remains neutral with regard to jurisdictional claims in published maps and institutional affiliations.

\section{Author details}

${ }^{1}$ Faculty of Business Management, Vilnius Gediminas Technical University, Sauletekio av. 11, LT-10223 Vilnius, Lithuania. ${ }^{2}$ Faculty of Engineering Economics and Management, Riga Technical University, Kalnciema str. 6, Riga LV-1048, Latvia.

Received: 1 July 2017 Accepted: 5 September 2017

Published online: 11 September 2017

\section{References}

Albaugh, Q. M. (2017). The Americanization of Canadian political science? The doctoral training of Canadian political science faculty. Canadian J Polit Sci, 50(1), 243-262.

Alcadipani, R., \& Caldas, M. P. (2012). Americanizing Brazilian management. Critical Perspectives on International Business, $8(1), 37-55$.

Adams, L. L. (2007). Globalization of culture and the arts. Sociology Compass, 1(1), 127-142.

Bond, C., \& O'Byrne, D. (2014). Challenges and conceptions of globalization: An investigation into models of global change and their relationship with business practice. Cross Cultural Management, 21(1), 23-38.

Bonin, H., \& de Goey, F. (2009). American firms in Europe- Strategy, identity, perception and performance. Geneve: Librairie Droz Burke, F. (2014). Buffalo bill in bologna: The Americanization of the world, 1869-1922. Am Nineteenth Century Hist, 15(3), 366-367. Butler, F. C. (1920). State Americanization: The Part of the State in the Education and Assimilation of the Immigrant. Bulletin, 1919, No. 77, Department of the Interior, Bureau of Education: Washington Government printing office.

Chun, A. (2012). The Americanization of pop culture in Asia? Inter-Asia Cultural Studies, 13(4), 495-506.

Craig, S. C., Douglas, S. P., \& Bennett, A. (2008). Contextual and cultural factors underlying Americanization. International Marketing Review, 26(1), 90-109.

Dahrir, W. (2013). Globalization as Americanization? Beyond the conspiracy theory. J Appl Phys, 5(2), 19-24.

First, A., \& Avraham, E. (2007). When the "holy land" turns into real estate: National Identity, globalization/ Americanization, and representation of the land in Israeli advertising. Popular Communication, 5(4), 223-239.

Graziano, P. R. \& Vink, M. P. (2013). Europeanization: Concept, Theory, and Methods, In book: The Member States of the European Union, Edition: Second Edition, Oxford University Press, Editors: Simon Bulmer, Christian Lesquene, pp.31-54.

Huebner, G. G. (1906). The Americanization of the immigrant. Ann Am Acad Pol Soc Sci, 27(May), 191-213.

Jiafeng, W. (2009). Some reflections on modernization theory and globalization theory. Chinese Studies in History, 43(1), 72-98.

Khaniha, N., \& Fard, Z. P. (2009). Globalization and important straits. Soc Sci, 4(3), 304-312.

Khondker, H. H. (2004). Glocalization as Globalization: Evolution of a Sociological Concept. Bangladesh e-Journal of Sociology 1(2), 12-20 Kuisel, R. (2001). Americanization for historians. Diplomatic History, 24(3), 509-515.

Lauret, M. (2013). When is an immigrant's autobiography not an immigrant autobiography? The Americanization of Edward Bok. Melus, 38(3), 7-24.

Lleras-Muney, A., \& Shertzer, A. (2015). Did the Americanization movement succeed? An evaluation of the effect of English-only and compulsory schooling Laws on immigrants. American Economic Journal: Economic Policy, 7(3), 258-290.

Oxelheima, L., \& Randoya, T. (2013). Globalization of monitoring practices: The caseof American influences on the dismissal risk of European CEOs. Journal of Economics and Business, 70, 3-15.

Maes, I., \& Buyst, E. (2005). Migration and Americanization: The special case of Belgian economic. Euro. J. History of Economic Thought, 12(1), 73-88.

von Mahs, J. (2011). Introduction-An Americanization of homelessness in post-industrial countries. Urban Geography, 32(7), 923-932.

Martens, P., Caselli, M., De Lombaerde, P., Figge, L., \& Scholte, J. A. (2015). New directions in globalization indices. Globalizations, 12(2), 217-228.

Minkevičius, R. (2015). Tarpukario Lietuvos reklama [Advertising in Interwar Lithuania]. Vilnius: BALTO print.

Nielsen, R. K. (2013). The absence of structural Americanization: Media system developments in six affluent democracies, 2000-2009. Int J Press/Politics, 18(4), 392-412.

Pekarskiene, I., \& Susniene, R. (2011). An assessment of the level of globalization in the Baltic states. Inzinerine Ekonomika-Engineering Economics, 22(1), 58-68.

Perobelli, F. S., \& De Oliveira, C. C. C. (2013). Energy development potential: An analysis of Brazil. Energy Policy, 59, 683-701.

Radu, L. (2009). Transnational companies and their role in globalization, LESIJ XVI(1) (pp. 396-406).

Ritzer, G. (1983). "The McDonaldization of society", journal of American culture, no. 6 (pp. 100-107).

Ritzer, G., \& Chen, C. C. (2015). McDonaldization, international encyclopedia of the Social \& Behavioral Sciences (pp. 828-830).

Scheindlin, D. (2017). Impact of American political marketing on Israeli Societ. J Political Mark, 16(1), 23-49.

Šimelytė, A., Peleckis, K., \& Korsakienè, R. (2014). Analytical network process based on BOCR analysis as an approach for designing a foreign direct investment policy. Journal of Business Economics and Management, 15(5), 833-852.

Tipps, D. (1973). Modernization theory and the comparative study of societies. Comparative Studies in Society and History, 15, $199-240$.

Tomja, A. (2013). Dilemma: Americanization or globalization. Int J Interdisciplinary Res, 1(3), 567-572.

Xifra, J. (2011). Americanization, globalization, or modernization of electoral campaigns? Testing the situation in Spain American Behavioral Scientist, 55(6), 667-682

Yun, J. H. J., Park, K., Kim, J., \& Yang, J. (2016). Open innovation effort, entrepreneurship orientation, and their synergies onto innovation performance in SMEs of Korea. Sci Technol Soc, 21(3), 366-390.

Yun, J. H. J., Yang, J., \& Park, K. (2016). Open innovation to business model: New perspective to comment between technology and market. Sci Technol Soc, 21(3), 1-25.

Yun, J. H. J. (2015). How do we conquer the growth limits of capitalism? Schumpeterian dynamics of open innovation. J Open Innovation: Technology, Market, and Complexity, 17, 1-20.

Zinkina, J., Korotayev, A., \& Andreev, A. (2013). Measuring globalization: Existing methods and their implications for teaching global studies and forecasting. Campus-Wide Information Systems, 30(5), 321-339. 